\title{
Adult Spinal Cord Ependymoma
}

National Cancer Institute

\section{Source}

National Cancer Institute. Adult Spinal Cord Ependymoma. NCI Thesaurus. Code C27399.

An ependymoma of the spinal cord occurring in adults. 